\title{
Sistem Pedukung Keputusan Penentuan Pemilihan Smartphone bagi Pengguna
}

\author{
Nining Suryani \\ Program Studi Manajemen Informatika \\ AMIK BSI Karawang, Jl. Banten No.1, Karangpawitan, Karawang, Jabar \\ nining.nns@bsi.ac.id
}

\begin{abstract}
Abstrak
Kehadiran smartphone memberikan banyak manfaat diantaranya adalah komunikasi menjadi lebih praktis dan efesien, karena dengan smartphone kita dapat berkomunikasi dimana dan kapan saja. Beragamnya smartphone yang ditawarkan dan daya beli masyarakat yang semakin tinggi dengan kriteria-kriteria yang ada, mulai dari daya guna, sistem operasi sampai dengan jaringannya, sehingga memicu timbulnya masalah yang membuat konsumen bingung dalam menentukan produk smartphone yang sesuai dengan keinginan. Kondisi tersebut biasanya sering dialami konsumen ketika ingin mencoba menentukan keputusan dalam membeli sebuah smartphone, sehingga tak heran jika konsumen kadang salah memilih smartphone yang sesuai dengan kebutuhannya dikarenakan beragamanya tipe, spesifikasinya dan harga yang ditawarkan karenanya diperlukan rekomendasi kepada para pembeli handphone, untuk dapat memilih atribut, fitur, dan merek handphone berdasarkan spesifikasi handphone yang sesuai dengan kriteria yang diajukan, namun pengambilan keputusan akhirnya tetap ditentukan oleh pembeli. Metode yang digunakan untuk menentukan pemilihan adalah metode ANP. Dengan metode ini diharapkan konsumen tepat dalam memilih smartphone yang akan dibeli dan digunakan.
\end{abstract}

Kata kunci: ANP, Smartphone, Spk

The presence of smartphones provide many benefits including communication becomes more practical and efficient, because with a smartphone we can communicate where and anytime. The variety of smartphones offered and the higher purchasing power of the existing criteria, ranging from usability, operating system to network, so that trigger the emergence of problems that make consumers confused in determining smartphone products in accordance with the wishes. The condition is usually experienced by consumers when trying to determine the decision in buying a smartphone, so no wonder if consumers sometimes choose the wrong smartphone according to their needs due to the variety of types, specifications and prices offered therefore required recommendations to mobile phone buyers, to be able to choose the attributes, features, and brands of mobile phones based on the specification of mobile phones in accordance with the criteria proposed, but decision-making ultimately remains determined by the buyer. The method used to determine the selection is the ANP method. With this method is expected the right consumer in choosing a smartphone to be purchased and used.

Keywords: ANP, Smartphone, Spk

\section{Pendahuluan}

Pemakaian smartphone saat ini semakin diminati oleh khalayak ramai. Hampir semua kalangan, baik muda maupun tua menyukai benda ini dan banyak sekali vendor yang menciptakan smartphone dengan sistem operasi yang berbeda, dari sistem operasi windows sampai dengan android. Melihat antusias pemakai yang semakin hari semakin meningkat, vendor-vendor smartphone pun semakin memanjakan para pemakainya dengan mengeluarkan berbagai varian produk dan fitur yang semakin variatif. Kehadiran smartphone memberikan banyak manfaat diantaranya adalah komunikasi menjadi lebih praktis dan efesien, karena dengan smartphone kita dapat berkomunikasi dimana dan kapan saja. 
Beragamnya smartphone yang ditawarkan dan daya beli masyarakat yang semakin tinggi dengan kriteria-kriteria yang ada, mulai dari daya guna, sistem operasi sampai dengan jaringannya, sehingga memicu timbulnya masalah yang membuat konsumen bingung dalam menentukan produk smartphone yang sesuai dengan keinginan. Kondisi tersebut biasanya sering dialami konsumen ketika ingin mencoba menentukan keputusan dalam membeli sebuah smartphone, sehingga tak heran jika konsumen kadang salah memilih smartphone yang sesuai dengan kebutuhannya dikarenakan beragamanya tipe, spesifikasinya dan harga yang ditawarkan.

Saat ini sudah banyak vendor smartphone dari kelas lowend maupun midend yang mengusung tema Smartphone ber OS (Operating System) yaitu Smartphone (Telepon Pintar) seperti smartphone atau smartphone highend yang mahal lainnya yang menyediakan smartphone atau smartphone dengan harga yang murah dan terjangkau dengan fasilitas yang menggiurkan, karena perkembangan yang luar biasa ini para vendor smartphone semakin mengutamakan kemewahan dan memanjakannya dengan fitur-fitur yang menarik mulai dari yangdigunakan hanya untuk alat komunikasi hingga alat untuk internet mobile dengan multimedia yang lengkap.

Meningkatnya perkembangan teknologi informasi saat ini tidak dibarengi dengan meningkatnya pengetahuan pengguna smartphone karena masih banyak para pengguna smartphone yang belum mengetahui teknologi smartphone seperti apa yang sesuai dengan keinginan dan kebutuhan dengan beberapa kriteria yang diinginkan sehingga diperlukan suatu aplikasi untuk memberikan saran dan rekomendasi kepada para pembeli smartphone, untuk dapat memilih atribut, fitur, dan merek smartphone berdasarkan spesifikasi smartphone yang sesuai dengan kriteria yang diajukan, namun pengambilan keputusan akhirnya tetap ditentukan oleh pembeli.

Menurut Turban, Aronson \& Liang (2005:141), ada 14 karakter dan kapabilitas kunci dari sistem pemilihan keputusan yaitu dukungan untuk pengambil keputusan, terutama pada situasi semiterstruktur dan tak terstruktur, dengan menyertakan penilaian manusia dan informassi terkomputerisasi, dukungan untuk semu level manajerial, dari eksekutif puncak sampai manajer lini, dukungan untuk individu dan kelompok, dukungan untuk keputusan independen dan atau sekuensial, dukungan disemua fase proses pengambilan keputusan: intelegensi, desain, pilihan, dan implementasi, dukungan diberbagai proses dan gaya pengambilan keputusan, adaptivitas sepanjang waktu, pengguna merasa seperti di rumah. Ramah-pengguna, kapabilitas grafis yang sangat kuat, dan antarmuka manusia-mesin interaktif dengan satu bahasa alami dapat sangat meningkatkan keefektifan sistem pemilihan keputusan, $p$ eningkatan terhadap keefektifan pengambil keputusan (akurasi, timelines, kualitas) ketimbang pada efisiensinya (biaya pengambilan keputusan), kontrol penuh oleh pengambil keputusan terhadap semua langkah proses pengambilan keputusan dalam memecahkan suatu masalah, pengguna akhir dapat mengembangkan dan memodifikasi sendiri sistem sederhana, biasanya model-model digunakan untuk menganalisis situasi pengambilan keputusan, akses disediakan untuk berbagai sumber data, format, dan tipe, mulai dari sistem informasi geografis (GIS) sampai system berorientasi-objek, dapat dilakukan sebagai alat standalone yang digunakan oleh seorang pengambil keputusan pada satu lokasi atau didistribusikan di satu organisasi keseluruhan dan di beberapa organisasi sepanjang rantai persediaan.

Fase-fase proses pengambilan keputusan menurut Simon (1977) dalam Turban, Aronson \& Liang (2005:64) meliputi empat fase utama, yaitu:

1. Fase Inteligensi, meliputi scanning (pemindaian) lingkungan, entah secara intermiten ataupun terus-menerus. Fase inteligensi dimulai dengan identifikasi terhadap tujuan dan sasaran organisasional yang berkaitan dengan isu yang diperhatikan dan determinasi apakah tujuan tersebut telah terpenuhi.

2. Fase Design, meliputi penemuan atau pengembangan dan menganalisis tindakan yang mungkin untuk dilakukan. Hal ini meliputi pemahaman terhadap masalah dan menguji solusi yang layak. 
3. Fase Pilihan, merupakan tindakan pengambilan keputusan yang kritis. Fase pilihan adalah fase di mana dibuat suatu keputusan yang nyata dan diambil suatu komitmen untuk mengikuti suatu tindakan tertentu.

4. Fase Implementasi, berarti membuat suatu solusi yang direkomendasikan bisa bekerja, tidak memerlukan implementasi suatu sistem komputer.

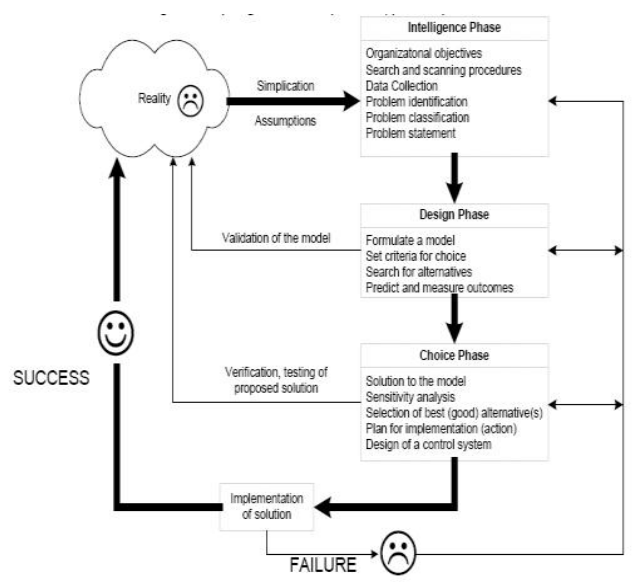

Gambar.1 Pengambilan keputusan/proses pemodelan Sumber: Turban, dkk.(2005:65)

Berdasarkan penelitian yang dilakukan Henri dan Aprianti (2017:19) masyarakat melakukan pemilihan handphone berdasarkan gengsi semata sehingga timbul kesulitan dalam memilih smartphone yang diinginkan sesuai dengan kebutuhan karenanya dilakukan penelitian untuk merancang sistem pemilihan yang terkomputerisasi yang dapat memberikan solusi dengan memperoleh keputusan yang baik dalam memilih smartphone yang sesuai dengan keinginan dan kebutuhannya dengan metode simple additive weighting yang menggunakan beberapa alternatif dan kriteria yang akan dijadikan acuan serta menentukan bobot preferensi, kemudian dilakukan peniaian dan perankingan smartphone- smartphone yang telah diurutkan dari yang tertinggi hingga yang terendah berdasarkan hasil penjumlahan terbobot yang telah terhitung.

Berdasarkan penelitian sebelumnya yang dilakukan oleh astari dan kuswani (2017:6) yang berjudul sistem Pendukung Keputusan Pemilihan Smartphone Terbaru menggunakan Metode Analytical Hierarchy
Process (AHP) dalam metode AHP jika terdapat permasalahan pada uji konsistensi, seperti nilai Consistency Index yang terlalu tinggi dan menyebabkan hasil tidak konsisten, maka perlu dilakukan pertimbangan kembali dan mengevaluasi kembali masing-masing input hingga hasil tersebut konsisten. Hal ini akan sulit dilakukan dan memakan waktu jika jumlah kriteria maupun sub kriteria terlalu banyak.

Menurut Triajeng dan Titis
$(2017: 70)$ yang berjudul Penerapan Analytic Network Process (ANP) Pada Sistem Pendukung Keputusan.menyatakan bahwa aplikasi ANP ini sudah bersifat dinamis, sehingga jumlah kriteria yang diproses dapat jumlah kurang dari 5 dan nama kriteria serta bobot dari masingmasing kriteria dapat diubah sesuai dengan kebutuhan pengguna.

Berdasarkan uraian diatas maka dapat dilakukan penelitian untuk melihat apakah metode ANP dapat digunakan dalam sistem pendukung yang dapat mengolah data dengan jumlah kriteria maupun sub kriteria terlalu banyak.

\section{Metode Penelitian}

Dalam penelitian ini, ada beberapa tahapan penelitian yang dilakukan guna mencapai tujuan yang telah ditetapkan. Hal ini dapat dilihat pada sebuah rancangan penelitian berupa langkah-langkah seperti ditunjukkan Gambar 1.

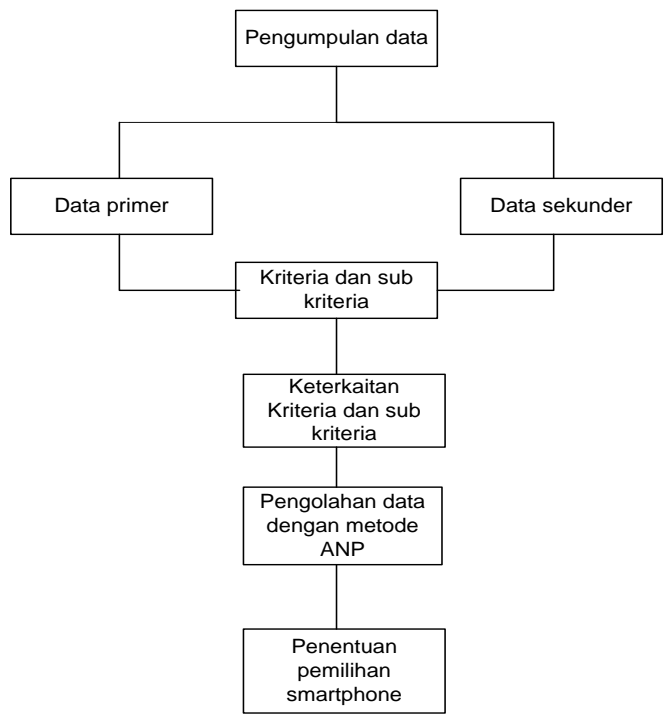

Gambar 2. Kerangka Penelitian 
Pengumpulan data, untuk mendapatkan data primer dilakukan dengan wawancara dan penyebaran kuesioner sedangkan data sekunder diperoleh dengan mencari referensi dari studi literatur.

Kriteria dan sub kriteria, tahap ini merupakan tahap mengidentifikasi kriteria dan sub kriteria yang dijadikan pertimbangan dalam pemilihan smartphone.

Keterkaitan kriteria dan sub kriteria, tahap ini untuk mengidentifikasi bagaimana hubungan yang terjadi antara kriteria dan sub kriteria tersebut.

Pengolahan data, yaitu dengan melakukan inventarisasi dan klasifikasi data yang terkumpul dari lapangan berdasarkan kategori pemenuhan karakteristik data yang sudah ditentukan. Entri data akan dilakukan setelah data divalidasi dan sudah layak untuk diolah. Data akan diolah menggunakan konsep ANP menggunakan metode ANP dan super decision.

Penentuan Pemilihan ini menggunakan metode ANP untuk membantu dalam pengambilan keputusan pemilihan smartphone. Dalam penentuannya terdapat 5 kriteria dan 4 alternatif yaitu:

Kriteria : fitur, teknologi, desain, harga, baterai

Alternatif : BlackBerry, Samsung, iPhone,Oppo

Berdasarkan Maede dalam Triajeng dan Titis (2017:67) yang berjudul Penerapan Analytic Network Process (ANP) Pada Sistem Pendukung Keputusan.menyatakan Langkah-langkah dalam ANP Berikut ini adalah lima langkah pembuatan ANP

1: Buat suatu hirarki jaringan keputusan yang menunjukkan hubungan antar faktor keputusan

2: Buat matriks perbandingan berpasangan diantara faktor yang mempengaruhi keputusan

3: Hitung relative importance weight vectors dari faktor-faktor yang ada

4: Pembentukan supermatriks dan analisis

Supermatriks yaitu suatu matrik yang tersusun dari relative importance weight vectors. Kemudian menormalisasikan supermatriks tersebut sehingga angka-angka di dalam tiap-tiap kolom pada supermatriks memiliki jumlah bernilai 1 (satu).

5: Menghitung bobot akhir Hitunglah bobot akhir dengameningkatkan supermatriks dengan $2 n+1$ dimana $k$ merupakan sembarang angka yanbesar sampai stabilitas bobot terjadi, dimannilai-nilai dalam supermatriks tidak berubahketika dikalikan dengan dirinya sendiri, atausering disebut konvergen.

Menurut Sugiyono (2012:244) analisis data adalah proses mencari dan menyusun secara sistematis data yang diperoleh dari hasil wawancara, catatan lapangan, dan dokumentasi dengan cara mengorganisasikan data ke dalam kategori, menjabarkan ke dalam unit-unit, melakukan sintesa, menyusun ke dalam pola, memilih mana yang lebih penting dan yang akan dipelajari, dan membuat kesimpulan sehingga mudah dipahami oleh diri sendiri maupun orang lain.

\section{Hasil dan Pembahasan}

Dalam penelitian ditetapkan populasi yang merupakan sejumlah pemilik toko smartphone di wilayah kelurahan pondok labu dan kelurahan sawangan. Sampel merupakan objek yang diobservasi peneliti dengan melakukan penarikan sampel secara simple random sampling dan penyebaran kuesioner kepada beberapa pemilik toko.

Perbandingan kriteria dan sub kriteria akan di gambarkan sebagai berikut: Tabel 1. kriteria dan sub kriteria

\begin{tabular}{|c|c|c|c|}
\hline Kriteria & Sub kriteria & Kriteria & Sub kriteria \\
\hline \multirow{4}{*}{ alternative } & $\mathrm{bb}$ & \multirow{5}{*}{ design } & Banyak varian \\
\hline & samsung & & $\begin{array}{l}\text { Bentuk } \\
\text { fashionable }\end{array}$ \\
\hline & iphone & & Bentuk mungil \\
\hline & oppo & & Ringan \\
\hline \multirow{5}{*}{ Fitur } & Fasilitas & & $\begin{array}{l}\text { Rancangan } \\
\text { yang sesuai }\end{array}$ \\
\hline & $\begin{array}{l}\text { ketajaman } \\
\text { warna }\end{array}$ & \multirow{4}{*}{ harga } & Garansi lama \\
\hline & layar & & Harga kompetitif \\
\hline & $\begin{array}{l}\text { iternet } \\
\text { mobile }\end{array}$ & & $\begin{array}{l}\text { Pelayanan } \\
\text { purna jual }\end{array}$ \\
\hline & multimedia & & $\begin{array}{l}\text { Harga jual } \\
\text { kembali stabil }\end{array}$ \\
\hline \multirow[t]{2}{*}{ Teknologi } & $\begin{array}{l}\text { touch } \\
\text { screen }\end{array}$ & \multirow[t]{2}{*}{ baterai } & $\begin{array}{l}\text { lama } \\
\text { penggunaan }\end{array}$ \\
\hline & touch pad & & lama isi ulang \\
\hline
\end{tabular}




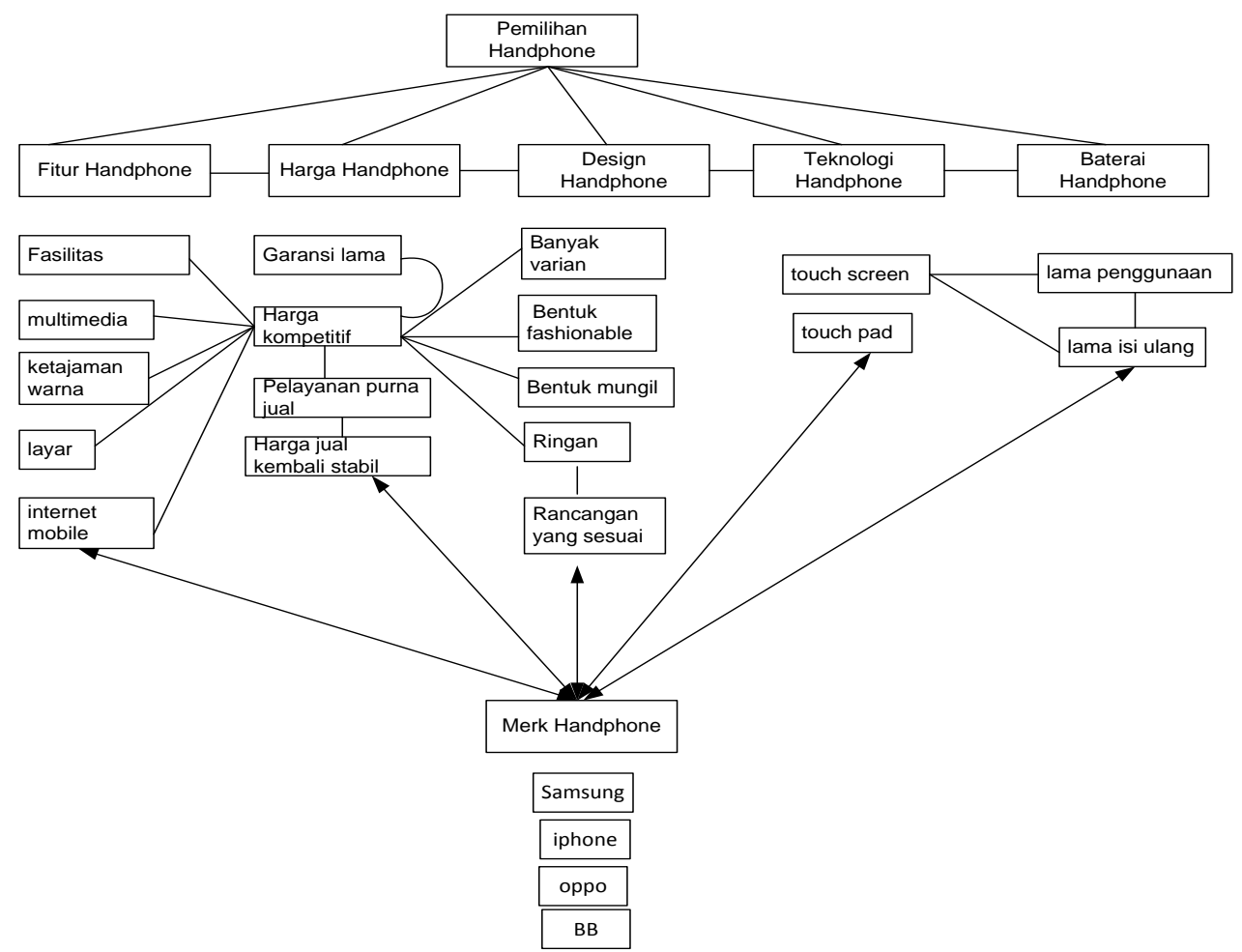

Gambar 3. Model pengambilan keputusan pemilihan smartphone oleh pemakai

Gambar 3 menggambarkan model pengambilan keputusan pemilihan smartphone oleh pemakai dengan sistem pendukung keputusan.

Setelah mendapatkan model dilanjutkan dengan melakukan pairwise comparisons terhadap kriteria dan sub kriterianya dengan menggunakan super decission.

a. Pemilihan smartphone dengan alternatif smartphone BB

1. Pemilihan smartphone dengan alternatif smartphone BB terhadap kriteria fitur dan sub kriterianya.

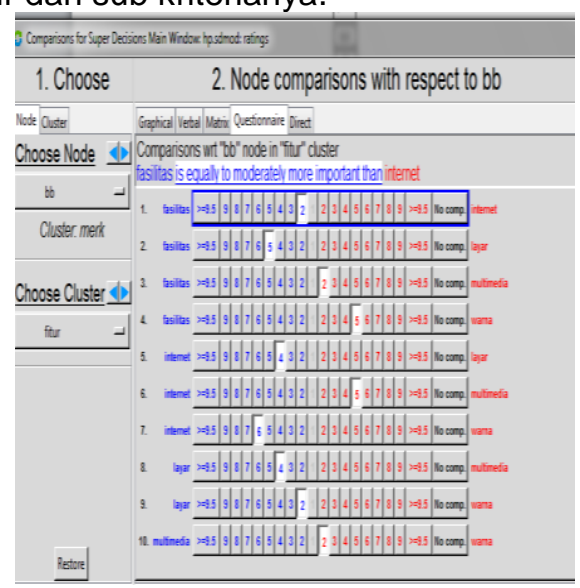

Gambar 4. Comparisons BB terhadap Fitur
Berdasarkan gambar diatas dilakukan keterkaitan hubungan antara kriteria fitur terhadap subkriterianya yaitu fasilitas, internet, layar, multimedia dan warna sehingga menghasilkan 10 perbandingan. Setelah pengolahan data dari 10 perbandingan tersebut menghasilan subkriteria yang lebih penting seperti yang tertera dibawah ini:

Tabel 2. Comparison BB terhadap Fitur

\begin{tabular}{|l|l|}
\hline Name & Normalized \\
\hline fasilitas & 0.18744952442639326 \\
\hline internet & 0.23594929485402086 \\
\hline layar & 0.17162982943995236 \\
\hline multimedia & 0.22286106253912866 \\
\hline warna & 0.18211028874050478 \\
\hline
\end{tabular}

Berdasarkan data diatas maka dari 5 subkriteria yang ada yang lebih penting adalah subkriteria internet.

2. Pemilihan smartphone dengan alternatif smartphone BB terhadap kriteria baterai dan sub kriterianya 


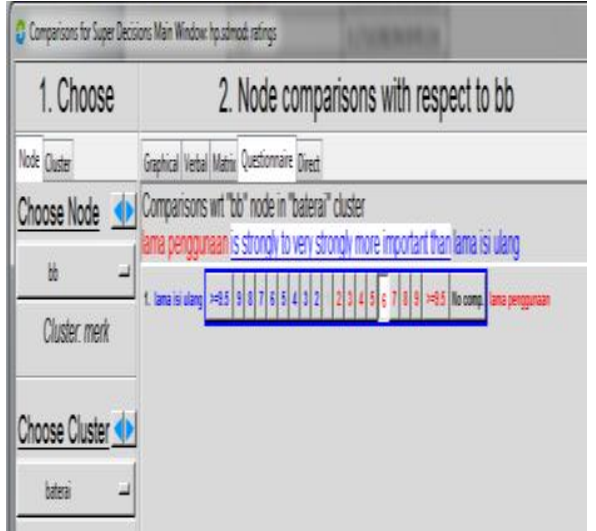

Gambar 5. Comparisons BB terhadap Baterai

Berdasarkan gambar diatas dilakukan keterkaitan hubungan antara kriteria fitur terhadap subkriterianya yaitu lama isi ulang dan lama penggunaan sehingga menghasilkan 1 perbandingan. Setelah pengolahan data dari 1 perbandingan tersebut menghasilan subkriteria yang lebih penting seperti yang tertera dibawah ini:

Tabel 3. Comparison BB terhadap Baterai

\begin{tabular}{|l|l|}
\hline Name & Normalized \\
\hline lama isi ulang & 0.14285738775503209 \\
\hline lama penggunaan & 0.85714261224496791 \\
\hline
\end{tabular}

Berdasarkan data diatas maka dari 2 subkriteria yang ada yang lebih penting adalah subkriteria lama penggunaan

3. Pemilihan smartphone dengan alternatif smartphone BB terhadap kriteria design dan sub kriterianya

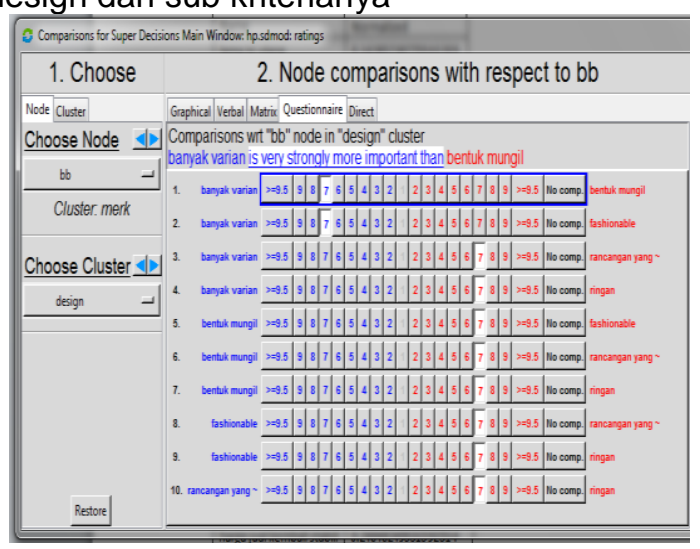

Gambar 6. Comparisons BB terhadap Design

Berdasarkan gambar diatas dilakukan keterkaitan hubungan antara kriteria fitur terhadap subkriterianya yaitu banyak varian, bentuk mungil, fashionable, rancangan yang sesuai dan ringan sehingga menghasilkan 10 perbandingan. Setelah pengolahan data dari 10 perbandingan tersebut menghasilan subkriteria yang lebih penting seperti yang tertera dibawah ini:

Tabel 4. Comparison BB terhadap Design

\begin{tabular}{|l|l|}
\hline Name & Normalized \\
\hline banyak varian & 0.1163985504839017 \\
\hline bentuk mungil & 0.024539691200608491 \\
\hline fashionable & 0.05344517617446079 \\
\hline rancangan yang sesuai & 0.25350536350749692 \\
\hline ringan & 0.55211121863353207 \\
\hline
\end{tabular}

Berdasarkan data diatas maka dari 5 subkriteria yang ada yang lebih penting adalah subkriteria ringan.

4. Pemilihan smartphone dengan alternatif smartphone BB terhadap kriteria harga dan sub kriterianya

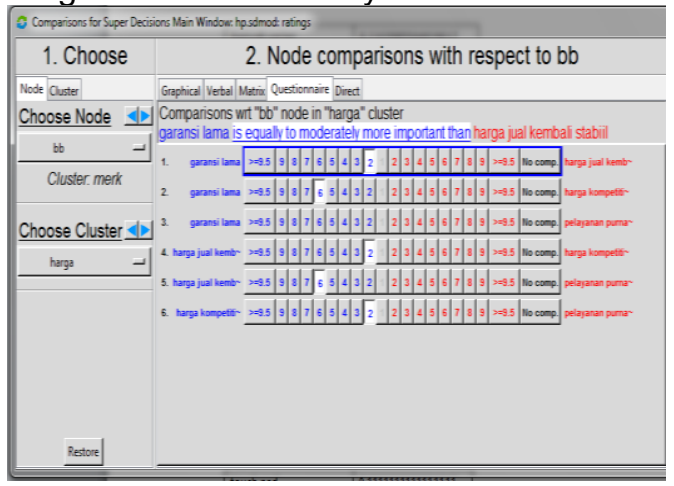

Gambar 7. Comparisons BB terhadap Harga

Berdasarkan gambar diatas dilakukan keterkaitan hubungan antara kriteria fitur terhadap subkriterianya yaitu garansi lama, harga jula kembali stabil, harga kompetitif dan pelayanan purna jual sehingga menghasilkan 6 perbandingan. Setelah pengolahan data dari 6 perbandingan tersebut menghasilan subkriteria yang lebih penting seperti yang tertera dibawah ini:

Tabel 5. Comparison BB terhadap Harga

\begin{tabular}{|l|l|}
\hline Name & Normalized \\
\hline garansi lama & 0.60866607566118824 \\
\hline harga jual kembali stabil & 0.24848249531592514 \\
\hline harga kompetitif & 0.10144101536578157 \\
\hline pelayanan purna jual & 0.041410413657104884 \\
\hline
\end{tabular}

Berdasarkan data diatas maka dari 4 subkriteria yang ada yang lebih penting adalah subkriteria garansi 
5. Pemilihan smartphone dengan alternatif smartphone BB terhadap kriteria teknologi dan sub kriterianya

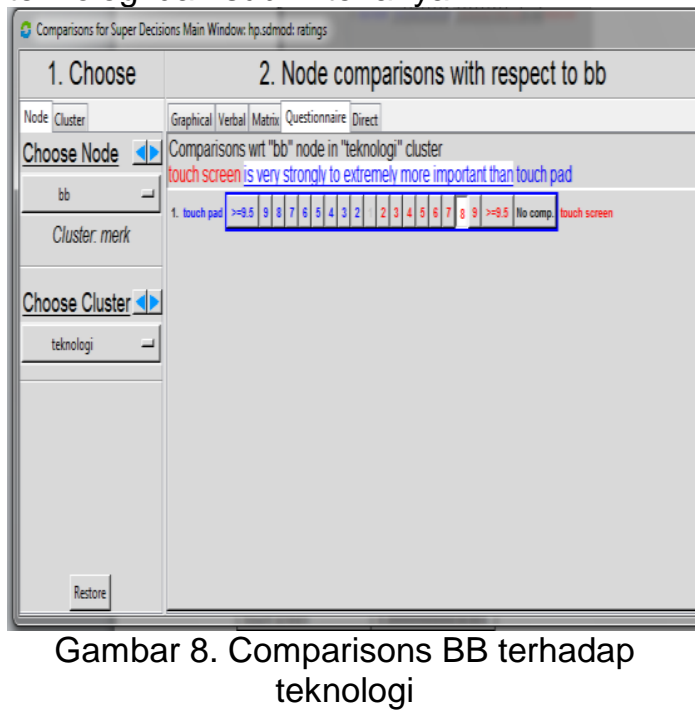

Berdasarkan gambar diatas dilakukan keterkaitan hubungan antara kriteria fitur terhadap subkriterianya yaitu touch pad dan touch screen sehingga menghasilkan 1 perbandingan. Setelah pengolahan data dari 1 perbandingan tersebut menghasilan subkriteria yang lebih penting seperti yang tertera dibawah ini:

Tabel 6. Comparison BB terhadap Teknologi

\begin{tabular}{|l|l|}
\hline Name & Normalized \\
\hline touch pad & 0.1111111111111111 \\
\hline touch screen & 0.88888888888888884 \\
\hline
\end{tabular}

Berdasarkan data diatas maka dari 2 subkriteria yang ada yang lebih penting adalah subkriteria touch screen

b. Pemilihan smartphone dengan alternatif smartphone Iphone

1. Pemilihan smartphone dengan alternatif smartphone Iphone terhadap kriteria baterai dan sub kriterianya

Tabel 7. Comparison Iphone terhadap Baterai

\begin{tabular}{|l|l|}
\hline Name & Normalized \\
\hline lama isi ulang & 0.1111111111111111 \\
\hline $\begin{array}{l}\text { lama } \\
\text { penggunaan }\end{array}$ & 0.88888888888888884 \\
\hline
\end{tabular}

Berdasarkan data diatas maka dari 2 subkriteria yang ada yang lebih penting adalah subkriteria touch screen
2. Pemilihan smartphone dengan alternatif smartphone Iphone terhadap kriteria design dan sub kriterianya

Tabel 8. Comparison Iphone terhadap Design

\begin{tabular}{|l|l|}
\hline Name & Normalized \\
\hline banyak varian & 0.1206493329192552 \\
\hline bentuk mungil & 0.025110869976062419 \\
\hline fashionable & 0.0624072995431025 \\
\hline rancangan yang sesuai & 0.24384255038725319 \\
\hline ringan & 0.54798994717432681 \\
\hline
\end{tabular}

Berdasarkan data diatas maka dari 5 subkriteria yang ada yang lebih penting adalah subkriteria ringan

3. Pemilihan smartphone dengan alternatif smartphone Iphone terhadap kriteria fitur dan sub kriterianya Tabel 9. Comparison Iphone terhadap Fitur

\begin{tabular}{|l|l|}
\hline Name & Normalized \\
\hline fasilitas & 0.56389811927468503 \\
\hline internet & 0.25018414465313082 \\
\hline layar & 0.10876227225198951 \\
\hline multimedia & 0.04958679244867472 \\
\hline warna & 0.02756867137151996 \\
\hline
\end{tabular}

Berdasarkan data diatas maka dari 5 subkriteria yang ada yang lebih penting adalah subkriteria fasilitas

4. Pemilihan smartphone dengan alternatif smartphone Iphone terhadap kriteria harga dan sub kriterianya

Tabel 10. Comparison Iphone terhadap harga

\begin{tabular}{|l|l|}
\hline Name & Normalized \\
\hline garansi lama & 0.63128685130253714 \\
\hline harga jual kembali stabil & 0.2422243065931225 \\
\hline harga kompetitif & 0.088127961982286909 \\
\hline pelayanan purna jual & 0.038360880122053631 \\
\hline
\end{tabular}

Berdasarkan data diatas maka dari 5 subkriteria yang ada yang lebih penting adalah subkriteria garansi lama

5. Pemilihan smartphone dengan alternatif smartphone Iphone terhadap kriteria teknologi dan sub kriterianya

Tabel 11. Comparison Iphone terhadap teknologi

\begin{tabular}{|l|l|}
\hline Name & Normalized \\
\hline touch pad & 0.1111111111111111 \\
\hline touch screen & 0.88888888888888884 \\
\hline
\end{tabular}


Berdasarkan data diatas maka dari 2 subkriteria yang ada yang lebih penting adalah subkriteria touch screen

c. Pemilihan smartphone dengan alternatif smartphone Oppo

1. Pemilihan smartphone dengan alternatif smartphone Oppo terhadap kriteria baterai dan sub kriterianya

Tabel 12. Comparison Iphone terhadap Baterai

\begin{tabular}{|l|l|}
\hline Name & Normalized \\
\hline lama isi ulang & 0.1111111111111111 \\
\hline $\begin{array}{l}\text { lama } \\
\text { penggunaan }\end{array}$ & 0.88888888888888884 \\
\hline
\end{tabular}

Berdasarkan data diatas maka dari 2 subkriteria yang ada yang lebih penting adalah subkriteria lama penggunaan

2. Pemilihan smartphone dengan alternatif smartphone Oppo terhadap kriteria design dan sub kriterianya

Tabel 13. Comparison Iphone terhadap Design

\begin{tabular}{|l|l|}
\hline Name & Normalized \\
\hline banyak varian & 0.05511683548635269 \\
\hline bentuk mungil & 0.02624428806346631 \\
\hline fashionable & 0.1085531525144003 \\
\hline $\begin{array}{l}\text { rancangan yang } \\
\text { sesuai }\end{array}$ & 0.24330692775661561 \\
\hline ringan & 0.56677879617916505 \\
\hline
\end{tabular}

Berdasarkan data diatas maka dari 5 subkriteria yang ada yang lebih penting adalah subkriteria ringan

3. Pemilihan smartphone dengan alternatif smartphone Oppo terhadap kriteria fitur dan sub kriterianya

Tabel 14. Comparison Iphone terhadap Fitur

\begin{tabular}{|l|l|}
\hline Name & Normalized \\
\hline fasilitas & 0.56064280967519897 \\
\hline internet & 0.23648907201005245 \\
\hline layar & 0.11638116151679337 \\
\hline multimedia & 0.026873612923021012 \\
\hline warna & 0.059613343874934069 \\
\hline
\end{tabular}

Berdasarkan data diatas maka dari 5 subkriteria yang ada yang lebih penting adalah subkriteria fasilitas

4. Pemilihan smartphone dengan alternatif smartphone Oppo terhadap kriteria harga dan sub kriterianya
Tabel 15. Comparison Iphone terhadap Harga

\begin{tabular}{|l|l|}
\hline Name & Normalized \\
\hline garansi lama & 0.66755118729296758 \\
\hline harga jual kembali stabil & 0.20930069198854712 \\
\hline harga kompetitif & 0.086334989650804023 \\
\hline pelayanan purna jual & 0.03681313106768138 \\
\hline
\end{tabular}

Berdasarkan data diatas maka dari 4 subkriteria yang ada yang lebih penting adalah subkriteria garansi lama

5. Pemilihan smartphone dengan alternatif smartphone Oppo terhadap kriteria teknologi dan sub kriterianya

Tabel 16. Comparison Iphone terhadap Teknologi

\begin{tabular}{|l|l|}
\hline Name & Normalized \\
\hline touch pad & 0.1249998906249863 \\
\hline $\begin{array}{l}\text { touch } \\
\text { screen }\end{array}$ & 0.87500010937501371 \\
\hline
\end{tabular}

Berdasarkan data diatas maka dari 2 subkriteria yang ada yang lebih penting adalah subkriteria touch screen

d. Pemilihan smartphone dengan alternatif smartphone Samsung

1. Pemilihan smartphone dengan alternatif smartphone Samsung terhadap kriteria baterai dan sub kriterianya

Tabel 17. Comparison Iphone terhadap Baterai

\begin{tabular}{|l|l|}
\hline lama isi ulang & 0.1249998906249863 \\
\hline lama penggunaan & 0.87500010937501371 \\
\hline
\end{tabular}

Berdasarkan data diatas maka dari 2 subkriteria yang ada yang lebih penting adalah subkriteria lama penggunaan

2. Pemilihan smartphone dengan alternatif smartphone Samsung terhadap kriteria design dan sub kriterianya

Tabel 18. Comparison Iphone terhadap Design

\begin{tabular}{|l|l|}
\hline Name & Normalized \\
\hline banyak varian & 0.041880317537316337 \\
\hline bentuk mungil & 0.02120478016665903 \\
\hline fashionable & 0.28014439954164289 \\
\hline $\begin{array}{l}\text { rancangan yang } \\
\text { sesuai }\end{array}$ & 0.31013912708411151 \\
\hline ringan & 0.34663137567027019 \\
\hline
\end{tabular}

Berdasarkan data diatas maka dari 5 subkriteria yang ada yang lebih penting adalah subkriteria ringan 
3. Pemilihan smartphone dengan alternatif smartphone Samsung terhadap kriteria fitur dan sub kriterianya

Tabel 19. Comparison Iphone terhadap Fitur

\begin{tabular}{|l|l|}
\hline Name & Normalized \\
\hline fasilitas & 0.55374534183979129 \\
\hline internet & 0.28195264101458867 \\
\hline layar & 0.10751949063872063 \\
\hline multimedia & 0.014229710637603154 \\
\hline warna & 0.042552815869296268 \\
\hline
\end{tabular}

Berdasarkan data diatas maka dari 5 subkriteria yang ada yang lebih penting adalah subkriteria fasilitas

4. Pemilihan smartphone dengan alternatif smartphone Samsung terhadap kriteria harga dan sub kriterianya

Tabel 20. Comparison Iphone terhadap Harga

\begin{tabular}{|l|l|}
\hline Name & Normalized \\
\hline garansi lama & 0.64470150030932871 \\
\hline $\begin{array}{l}\text { harga jual kembali } \\
\text { stabiil }\end{array}$ & 0.2255985303054083 \\
\hline harga kompetitif & 0.09210021433216424 \\
\hline $\begin{array}{l}\text { pelayanan purna } \\
\text { jual }\end{array}$ & 0.03759975505309876 \\
\hline
\end{tabular}

Berdasarkan data diatas maka dari 4 subkriteria yang ada yang lebih penting adalah subkriteria garansi lama

5. Pemilihan smartphone dengan alternatif smartphone Samsung terhadap kriteria teknologi dan sub kriterianya
Tabel 21. Comparison Iphone terhadap Teknologi

\begin{tabular}{|l|l|}
\hline Name & Normalized \\
\hline touch pad & 0.1249998906249863 \\
\hline touch screen & 0.87500010937501371 \\
\hline Berdasarkan data diatas maka dari 2 \\
subkriteria yang ada yang lebih penting \\
adalah subkriteria touch screen
\end{tabular}

Selanjutkanya dilakukan pairwise pemilihan smartphone antara alternative yang ada.

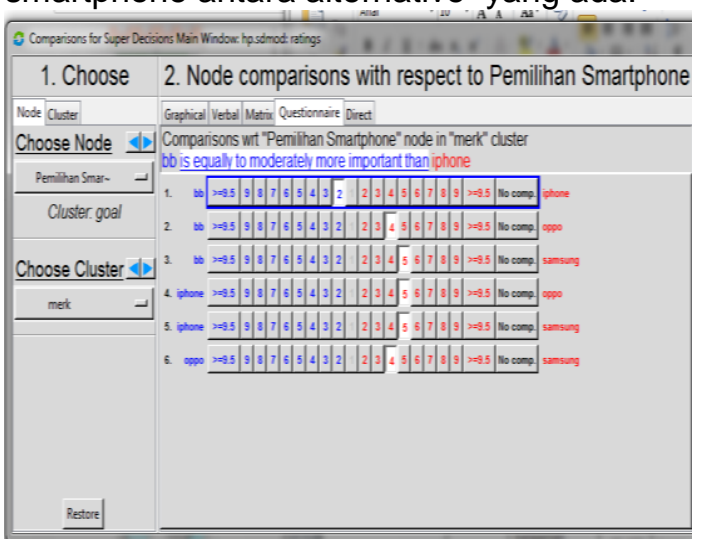

Gambar 9. Comparisons pemilihan smartphone

Berdasarkan gambar diatas dilakukan perbandingan antara alternative yang ada sehingga menghasilkan 6 perbandingan.

Setelah mendapatkan pairwise Comparison terhadap masing-masing kriteria lalu dilakukan pengolah data untuk menghitung nilai prioritas dari masing kriteria dan sub kriterianya, didapatkan nilai sebagai berikut :

Tabel 22. Nilai prioritas

\begin{tabular}{|l|l|r|l|l|r|}
\hline Kriteria & sub kriteria & $\begin{array}{l}\text { nilai } \\
\text { prioritas }\end{array}$ & Kriteria & sub kriteria & nilai prioritas \\
\hline alternative & BB & $10,32 \%$ & design & Banyak varian & $25,02 \%$ \\
\hline & samsung & $40,05 \%$ & & Bentuk fashionable & $14,13 \%$ \\
\hline & iphone & $25,62 \%$ & & Bentuk mungil & $21,73 \%$ \\
\hline & oppo & $24,01 \%$ & & Ringan & $32,01 \%$ \\
\hline & Fasilitas multimedia & $30,05 \%$ & & Rancangan yang sesuai & $7,11 \%$ \\
\hline & ketajaman warna & $20,12 \%$ & harga & Garansi lama & $27,14 \%$ \\
\hline & layar & $10,02 \%$ & & Harga kompetitif & $39,64 \%$ \\
\hline & iternet mobile & $14,80 \%$ & & Pelayanan purna jual & $11,24 \%$ \\
\hline & kamera & $25,01 \%$ & & Harga jual kembali stabil & $21,98 \%$ \\
\hline Teknologi & touch screen & $58,76 \%$ & baterai & lama penggunaan & $57,61 \%$ \\
\hline & touch pad & $41,24 \%$ & & lama isi ulang & $42,39 \%$ \\
\hline
\end{tabular}


Berdasarkan hasil dari tabel 22 nilai prioritas diatas bahwa nilai bobot dari masing masing kriteria. Untuk kriteria merek nilai bobot tertinggi pertama adalah samsung, kedua iphone, ketiga oppo dan terakhir bb. Selanjutnya untuk fitur nilai bobot tertinggi pertama adalah fasilitas multimedia, kedua kamera, ketiga ketajaman warna, keempat internet mobile dan terakhir adalah layar. Untuk teknologi, nilai bobot tertinggi pertama adalah touch screen dan terakhir adalah touch pad. Untuk design nilai bobot tertinggi pertama adalah ringan, kedua adalah banyak varian, ketiga adalah bentuk mungil, keempat adalah bentuk fashionable dan yang terakhir adalah rancangan yang sesuai. Untuk harga nilai bobot tertinggi pertama adalah harga kompetitif, kedua adalah garansi lama, ketiga adalah harga jual yang stabil dan yang terakhir adalah pelayanan purna jual. Untuk baterai nilai bobot tertinggi pertama adalah lama penggunaan dan terakhir lama isi ulang. Berdasarkan data yang telah dijabarkan diatas maka nilai prioritas tertinggi adalah prioritas yang dinilai dari yang lainnya.

\section{4, Kesimpulan}

Dari nilai pembobotan maka didapatkan kesimpulan dengan nilai pembobotan 40,05\% merk samsung menjadi prioritas dalam sistem pedukung keputusan penentuan pemilihan smartphone bagi pengguna.

Dengan nilai prioritas yang didaptkan memperlihatkan bahwa metode ANP dapat digunakan dalam sistem pendukung keputusan sehingga penelitian ini menggunakan metode ANP yang dapat mengolah data dengan jumlah kriteria maupun sub kriteria terlalu banyak.

\section{Referensi}

Fitriyani. 2012. Sistem Pendukung Keputusan Penjurusan SMA Menggunakan Metode AHP. ISSN: 979-26-0255-0. Semarang: Seminar Nasional Teknologi Informasi \& Komunikasi Terapan 2012 (Semantik 2012) 23 Juni 2012.

Darmanto, Eko, Noor Latifah \& Nanik Susanti. 2014. Penerapan Metode AHP (Analytic Hierarchy Process) Untuk Menentukan Kualitas Gula Tumbu. ISSN:2252-4983. Kudus:
Jurnal SIMETRIS. Vol. 5 No. 1, April 2014.

Dermawan, Risky. 2009. Model Kuantitatif Pengambilan Keputusan \& Perencanaan Strategis. Bandung: Alfabeta.

Hidayat, Yunan. 2014. Sistem Pendukung Keputusan Pemilihan Modem Menggunakan Metode Analytical Hierarchy Process (AHP). ISSN: 2301-9425. Medan: Pelita Informatika Budi Darma Vol. VI No. 1, Matret 2014. Diambil dari http://pelita-

informatika.com/berkas/jurnal/2.\%20 yunan\%20hidayat.pdf (23 Oktober 2014)

Harsiti dan Henri Aprianti. Sistem Pendukung Keputusan Pemilihan Smartphone dengan Menerapkan Metode Simple Additive Weighting (SAW). ISSN: 2406-7768. Jurnal Sistem Informasi Volume.4, Agustus 2017.

Kurniasih, Desi L. 2013. Sistem Pendukung Keputusan Pemilihan Laptop Dengan Metode TOPSIS. ISSN: $2301-9425$. Pelita Informatika Budi Darma, Vol. III, No. 2, April 2014.

Astari, Wirda Galvani Natasya dan Kusnawi. 2017. Sistem Pendukung Keputusan Pemilihan Smartphone Terbaru Menggunakan Metode Analytical Hierarchy Process (AHP). Informatika Universitas AMIKOM Yogyakarta

Marimin. 2005. Tehnik dan Aplikasi Pengambilan Keputusan Kriteria Majemuk. Jakarta: Grasindo.

Marimin, dkk. 2013. Tehnik dan Analisis Pengambilan Keputusan Fuzzy Dalam Manajemen Rantai Pasok. Bogor: IPB Press.

Revano, Rendhie \& Dwi Herlambang. Sistem Pendukung Keputusan Untuk Pembelian Mobil Merek Toyota Menggunakan Analytical Hierarchy Process. ISSN: 1978 - 0087. Surabaya: SCAN Vol. II, No. 1.

Siregar, Choirotunisah. 2014. Sistem Pendukung Keputusan Pemilihan Smartphone Bekas Dengan Menggunakan Metode Simple Additive Weighting (SAW). ISSN: 2301 - 9425. Medan: Pelita Informatika Budi Darma, Vol. VI, No. 1, Maret 2014. 
Permana, Sigit Budi. (2013). Sistem Pendukung Keputusan Pemilihan Program Studi di UIN Sunan Kalijaga Menggunakan Metode Analytical Hiererchy Process (AHP). Skripsi UIN Sunan Kalijaga Yogyakarta. Diambil dari www.academia.edu/6448006/Sistem Pendukung_Keputusan_Pemilihan Program_Studi. (24 Oktober 2014).

Riduwan, 2012. Skala Pengukuran Variabel-Variabel Penelitian. Bandung: Alfabeta.

Turban, Efraim, Jay E.Aronson, \& TingPeng Liang. 2005. Decision Support Systems and Intelligent Systems-7th Ed.Jilid 1 (Sistem Pendukung Keputusan dan Sistem Cerdas) Diterjemahkan oleh: Dwi Prabantini; Ed.1. Yogyakarta: Andi.
Sugiyono, 2012. Metode Penelitian Kuantitatif Kualitatif dan R\&D. Bandung: Alfabeta.

Supranto, J. 2009. Statistik Teori dan Aplikasi Edisi Ketujuh. Jakarta: Erlangga.

Sisca Budiarti dan Agus Widodo, " Pengambilan Keputusan MultiKriteriaMenggunakan Metode ANP (Analytic Network Process) Pada Evaluasi Supplier," 2013.

Triajeng Pungkasanti, Prind dan Titis Handayani.2017. Penerapan Analytic Network Process (ANP). Pada Sistem Pendukung Keputusan. Jurnal Transformatika, Volume 14, Nomor 2, Januari 2017 